\title{
Jump around: transposons in and out of the laboratory
}

\section{[version 1; peer review: 2 approved]}

\author{
Anuj Kumar (iD1,2 \\ ${ }^{1}$ Department of Molecular, Cellular, and Developmental Biology, University of Michigan, Ann Arbor, MI, USA \\ ${ }^{2}$ Program in Cellular and Molecular Biology, University of Michigan, Ann Arbor, MI, USA
}

V1 First published: 24 Feb 2020, 9(F1000 Faculty Rev):135
https://doi.org/10.12688/f1000research.21018.1

Latest published: 24 Feb 2020, 9(F1000 Faculty Rev):135

https://doi.org/10.12688/f1000research.21018.1

\section{Abstract}

Since Barbara McClintock's groundbreaking discovery of mobile DNA sequences some 70 years ago, transposable elements have come to be recognized as important mutagenic agents impacting genome composition, genome evolution, and human health. Transposable elements are a major constituent of prokaryotic and eukaryotic genomes, and the transposition mechanisms enabling transposon proliferation over evolutionary time remain engaging topics for study, suggesting complex interactions with the host, both antagonistic and mutualistic. The impact of transposition is profound, as over 100 human heritable diseases have been attributed to transposon insertions. Transposition can be highly mutagenic, perturbing genome integrity and gene expression in a wide range of organisms. This mutagenic potential has been exploited in the laboratory, where transposons have long been utilized for phenotypic screening and the generation of defined mutant libraries. More recently, barcoding applications and methods for RNA-directed transposition are being used towards new phenotypic screens and studies relevant for gene therapy. Thus, transposable elements are significant in affecting biology both in vivo and in the laboratory, and this review will survey advances in understanding the biological role of transposons and relevant laboratory applications of these powerful molecular tools.

\section{Keywords}

transposable elements, transposon mutagenesis, insertion library, phenotypic screening, genomics, CRISPR-Cas

\section{Open Peer Review}

Approval Status

1 2

version 1

$24 \mathrm{Feb} 2020$

Faculty Reviews are review articles written by the prestigious Members of Faculty Opinions. The articles are commissioned and peer reviewed before publication to ensure that the final, published version is comprehensive and accessible. The reviewers who approved the final version are listed with their names and affiliations.

1. Nancy Craig, Johns Hopkins School of Medicine, Baltimore, USA

2. Zoltán Ivics, Paul Ehrlich Institute, Langen, Germany

Any comments on the article can be found at the end of the article. 
Corresponding author: Anuj Kumar (anujk@umich.edu)

Author roles: Kumar A: Conceptualization, Funding Acquisition, Writing - Original Draft Preparation, Writing - Review \& Editing

Competing interests: No competing interests were disclosed.

Grant information: Relevant research in the Kumar laboratory was supported by grant 1902359 from the National Science Foundation (to A.K.).

The funders had no role in study design, data collection and analysis, decision to publish, or preparation of the manuscript.

Copyright: $\odot 2020$ Kumar A. This is an open access article distributed under the terms of the Creative Commons Attribution License, which permits unrestricted use, distribution, and reproduction in any medium, provided the original work is properly cited.

How to cite this article: Kumar A. Jump around: transposons in and out of the laboratory [version 1; peer review: 2 approved] F1000Research 2020, 9(F1000 Faculty Rev):135 https://doi.org/10.12688/f1000research.21018.1

First published: 24 Feb 2020, 9(F1000 Faculty Rev):135 https://doi.org/10.12688/f1000research.21018.1 


\section{Introduction}

Transposons are mobile repetitive genetic elements that are widespread throughout prokaryotic and eukaryotic genomes, considerably impacting many facets of biology, including genome evolution, genome composition, and human health ${ }^{1-5}$. The spread of multiresistant bacterial strains is an increasing healthcare problem worldwide, and the acquisition of pre-existing antibiotic resistance determinants is commonly achieved through the actions of mobile genetic elements, notably including transposons (reviewed in 6). Somatic transposition is increasingly being recognized for its biological and healthrelated significance. Postzygotic retrotransposition can occur in healthy and diseased cortical neurons and non-brain tissue ${ }^{7}$, and somatic retrotransposon insertions have been reported in cancer patients, with high retrotransposition rates in tumors associated with high rates of genomic rearrangement and somatic mutation $^{8,9}$. Transposon mobilization is highly mutagenic, as the insertion of a transposable DNA sequence is likely to perturb native gene expression and/or function at the locus of insertion ${ }^{10,11}$. The consequences of transposon insertion include open reading frame disruption, the alteration of promoter sequence, perturbed splicing and transcriptional termination, and epigenetic effects impacting nearby sequences. Consequently, organisms have established extensive mechanisms to combat transposition ${ }^{12-16}$. Despite these genome defense mechanisms, transposable elements constitute approximately $46 \%$ of the human genome ${ }^{17}$, and the interplay between transposition and host mechanisms is an ongoing area of study. This review will highlight current thought regarding this interplay, which involves commensal or mutualistic strategies. Recent studies have further shed light on the impact of transposition on the expression of genes at the locus of insertion, and these findings will be reviewed here. Transposons have been and remain a relevant tool in the laboratory, and this review will summarize several advances in the application of transposable elements for mutagenesis and molecular biology applications. Collectively, this review is designed to update our understanding of transposons in the context of evolutionary biology, molecular genetics, and biotechnology.

\section{Transposable elements and host interactions}

Transposable elements are predominantly viewed as "selfish" DNA elements, replicating to great numbers in many genomes $^{18}$. Although a full summary of transposon classes and structures is beyond the scope of this text, transposable elements have been divided into two large classes according to the employed method of transposition. Class 1 elements, or retrotransposons, transpose through an RNA intermediate by the action of reverse transcriptase. These elements can be subdivided into classes based on the presence or absence of long terminal repeats (LTRs) and further by the autonomy of the element-its ability to encode the necessary proteins for transposition. Long INterspersed Elements (LINEs) are autonomous non-LTR retrotransposons, and Short INterspersed Elements (SINEs) are non-autonomous and highly abundant non-LTR retrotransposons. Human Alu elements, each approximately 300 base pairs (bp) in length, are among the most abundant SINEs observed in any organism; over one million copies of
Alu elements are dispersed throughout the human genome ${ }^{17}$. Although immobile, endogenous retroviruses (ERVs) are a type of abundant retroelement, with human ERVs (HERVs) accounting for $8 \%$ of the human genome ${ }^{17}$. HERVs have shaped the evolution of the human genome, regulatory networks, and innate immune responses ${ }^{19}$. The residual expression capacity of many HERVs can regulate genes and influence host immunity ${ }^{20,21}$. Class 2 elements, or DNA transposons, transpose through a mechanism involving a DNA intermediate. DNA transposons are estimated to constitute over $3 \%$ of the human genome, encompassing at least 125 different families exhibiting a respective copy number of 100 or more ${ }^{22}$.

Transposon insertions are heritable and may spread vertically within a population and horizontally within species ${ }^{23,24}$. Natural selection and genetic drift are important determinants of the evolutionary fate of transposon insertions, with most extant insertions being neutral or only mildly deleterious to the host ${ }^{25}$. Upon initial transposition, however, the majority of insertions are presumed to be disruptive of gene function at the insertion locus. Additionally, transposon insertions, whether deleterious or not, may promote chromosomal rearrangements by providing foci for non-allelic homologous recombination ${ }^{1,26,27}$. Consequently, numerous mechanisms have evolved through which host organisms moderate or tolerate transposition.

A variety of regulatory mechanisms functioning at the transcriptional and post-transcriptional levels act to limit transposition. In eukaryotes other than plants, PIWI-interacting RNAs (piRNAs) are a primary and well-studied mechanism of transposon silencing ${ }^{14,28,29}$. piRNA-mediated inhibition of transposition is reviewed in Ozata et $a l .^{30}$. In animals and plants, small interfering RNAs (siRNAs) derived from transposable element loci trigger transposon silencing. Small RNAs can inhibit the transcription of neighboring genes at the site of transposon insertion through the deposition of repressive epigenetic modifications ${ }^{31}$. In mouse embryonic stem cells, transposable elements are suppressed by heterochromatic histone modifications, such as $\mathrm{H} 3 \mathrm{~K} 9 \mathrm{me} 3$, and are regulated by a host of epigenetic modifiers ${ }^{32}$. In mammals, Kruppel-associated box (KRAB) zinc-finger proteins bind transposable element sequences, with significant impact on retrotransposons, and recruit KRAB-associated protein-1 (KAP1/TRIM28), nucleating interactions with multiple proteins that generate a repressive chromatin architecture at the transposon insertion locus ${ }^{33-36}$.

DNA methylation has been recognized as an important mechanism combating transposition. Methylation and other means by which DNA modifications regulate transposition are reviewed in Deniz et $a l .{ }^{37}$. ATP-dependent chromatin remodelers in mammals and plants recruit methylases to produce a repressive chromatin state inhibiting transposition ${ }^{16,38,39}$. 5-methylcytosine is one of the more well-studied DNA modifications, and cytosine methylation is linked with repressed transposition ${ }^{40-44}$. In zebrafish embryos, global DNA hypomethylation caused by mutations in the DNA methyltransferase gene dnmt1 has been associated with widespread induction of class I retrotransposons and subsequent activation of cytoplasmic 
DNA sensors, mimicking a viral infection ${ }^{45}$. In early studies, Zhou and colleagues $^{46}$ found that the Neurospora crassa LINE-like Tad retrotransposon inserted in the 5'-non-coding sequence of the am glutamate dehydrogenase gene carries a de novo cytosine methylation signal that causes reversible methylation of Tad and am upstream sequences. This methylation inhibits Tad expression and transposition, and the inhibition can be relieved by treatment with the drug 5-azacytidine, which reduces cytosine methylation. In addition to 5-methylcytosine, several studies suggest a role for N6-methyladenine in regulating transposition ${ }^{47,48}$. N6-methyladenine has been identified across prokaryotes, archaea, and eukaryotes, although it is not abundant in metazoans ${ }^{49-52}$. In Escherichia coli, activity of the Tn10 transposon is highly elevated in strains with decreased levels of N6-methyladenine from mutation of the dam N6-methyladenine methyltransferase ${ }^{48}$. In zebrafish, N6methyladenine is enriched at repetitive elements, including LINE-1, LTR, and DNA transposable elements ${ }^{53}$.

As proposed by Barbara McClintock and subsequent researchers, transposons have evolved commensal or mutualistic strategies with host organisms, contributing to the widespread evolutionary success of transposable elements ${ }^{54}$. Mutualism has been commonly observed in prokaryotes, as transposons and conjugative plasmids frequently shuttle antibiotic resistance genes $^{55}$. Prokaryotic mobile genetic elements may carry genes beneficial to their host, encoding secretion proteins, cation efflux pumps, copper resistance proteins, and proteins in restriction modification systems ${ }^{56}$. Numerous catabolic genes are present on transposons, including insertion sequence composite transposons, underlying the tendency of many catabolic genes to undergo genetic rearrangements ${ }^{57}$. The origin of the CRISPR (Clustered Regularly Interspaced Palindromic Repeats)-Cas system presents a striking example of mutualism between host and mobile genetic elements. Over the past 15 years, we have observed the widespread recognition of CRISPR-Cas systems as an adaptive immune response in bacteria and $\operatorname{archaea}^{58-61}$. By these well-studied systems, "spacer" sequences from phage and plasmids are inserted into CRISPR sequence arrays; resulting CRISPR transcripts are processed, such that the phage sequences are loaded onto Cas proteins for recognition of the foreign genome. The CRISPR-Cas adaptation module for the integration of foreign DNA fragments as unique spacers in the CRISPR array is proposed to have evolved from a superfamily of Cas1encoding genetic elements that were likely mobile, termed Casposons (reviewed in 62,63).

Examples of mutualism are also evident in eukaryotes. In jawed vertebrates, the Recombination Activating Gene (RAG) proteins 1 and 2 mediate the site-specific double-stranded DNA breaks necessary for $\mathrm{V}(\mathrm{D}) \mathrm{J}$ recombination and share mechanistic and structural similarities with several families of transposases ${ }^{64}$. Notably, the RAG proteins are thought to have evolved from the ProtoRAG DNA transposon family ${ }^{65}$. ProtoRAG was demonstrated to encode RAG1- and RAG2-like proteins that constitute an active endonuclease and transposase in vitro and in living cells ${ }^{65}$, and structural analysis through $\mathrm{X}$-ray crystallography and cryo-electron microscopy of the
RAG1-like transposase Transib from the moth Helicoverpa zea has identified many mechanistic details relevant to our understanding of cut-and-paste transposition ${ }^{66}$. Transposable elements may contribute to the establishment of telomerelike sequences in Drosophilid species lacking telomerase. In nearly all Drosophila species, telomeric repeats have been replaced with arrays of non-LTR retrotransposon sequences ${ }^{67}$. In Drosophila melanogaster, three families of Jockey-like retrotransposons act cooperatively to enable their own amplification and, consequently, the maintenance of telomeric sequence ${ }^{68,69}$. Furthermore, the G2/Jockey-3 family of non-LTR retrotransposons contributes directly to the function and organization of centromeric sequences in D. melanogaster ${ }^{70}$. Transposable elements can carry virulence genes in some fungal pathogens ${ }^{71}$. In the ciliate Oxytricha trifallax, a family of DNA transposons are mobilized during meiosis, cooperatively contributing to the remodeling of the germline micronucleus and somatic macronucleus. RNAi-based silencing of the transposases encoded by this family of transposons impairs cell growth and causes cell death owing to aberrant micronuclear and macronuclear development ${ }^{72-75}$. Proteins derived from ERVs have been coopted repeatedly to promote cell-cell fusion, regulate the expression of genes important for human pregnancy, and modulate immune responses in the placenta ${ }^{76,77}$. Cosby et al. ${ }^{54}$ further review host-transposon interactions towards understanding the impact of transposition on genome organization and biology.

\section{Transposable elements modulate gene expression}

Transposons are highly abundant in genomes and can encode promoter sequences, splice sites, transcriptional terminator sequences, binding sites for multiple transcription factors, and sequences that modify chromatin conformation ${ }^{78-80}$. Consequently, transposable elements play significant roles in regulating the expression of nearby genes $^{81}$, and important findings elucidating the regulatory role of transposons in modulating gene expression are reviewed in Rebello et al. ${ }^{82}$.

From an evolutionary perspective, transposable elements may have played an important role in the development of transcriptional regulatory networks, as internal promoters and binding sites for host transcription factors are evident in transposable element sequences ${ }^{83}$. Transposition may have promoted the distribution of these regulatory elements, with subsequent selection resulting in the evolution of regulatory pathways $^{84,85}$. Among these regulatory elements, enhancerlike epigenetic features have been identified, particularly in the LTRs of ERVs. Todd et al. ${ }^{86}$ identified a large set of putative enhancers overlapping with ERV-encoded LTRs in mouse embryonic and trophoblast stem cells, although in situ evaluation of enhancer activity indicates that the majority of these elements do not exhibit enhancer function. Work in humans ${ }^{87,88}$ indicates that primate-specific LTRs encoding putative enhancers impact gene transcription in situ to a greater degree than do the elements observed in mouse stem cells, highlighting the need for further consideration of these sequences. Tellier and Chalmers $^{89}$ identified a broad impact on the human transcriptome from the SETMAR protein methylase, which is a fusion between a SET-domain protein methylase and the HsMarl transposase. This work demonstrates that the DNA-binding 
domain of the transposase targets the enzyme to residual transposon-end sequences, allowing for the regulation of gene expression dependent on methylase activity.

Recently, Gagliardi and colleagues ${ }^{90}$ identified an interesting transposon-based mechanism for the regulation of gene expression at the HaWRKY6 locus in the sunflower genome. Analysis of expressed sequence tags corresponding to this locus revealed a non-coding RNA derived from an inverted repeat (IR) of the Miniature IR Transposable Element (MITE) family situated 600-800 bp upstream of the HaWRKY6 transcriptional start site. MITEs are 50-to-500 bp non-autonomous transposable elements with terminal IRs typically found in gene-rich regions of plant genomes ${ }^{91}$. Transcripts from the IR elements are processed into 24-nucleotide siRNAs, which trigger DNA methylation and nucleate the formation of tissue-specific chromatin loops at the HaWRKY6 locus (Figure 1). In sunflower leaves, an intragenic loop forms, comprising the regulatory region of the HaWRKY6 gene up to its fourth intron. This looped conformation inhibits the expression of HaWRKY6, likely by blocking movement of RNA polymerase II. In cotyledons, however, an alternative loop forms, encompassing the full HaWRKY6 gene and enhancing its transcription. The formation of this loop changes RNA polymerase II directionality, which may reduce transcription of the IR region, decrease siRNA production, and ultimately release the looped conformation. This elegant mechanism highlights the broad, and potentially undiscovered, functions that transposons may fulfill in regulating gene expression.

\section{Transposon-based phenotypic screening}

Transposons have been employed at length as laboratory reagents for the facile construction of mutants, including gene disruption/replacement alleles, promoter fusions resulting in altered timing and levels of transcription, and translational fusions for the construction of various chimeras including epitope/fluorescent protein-tagged products. Relative to chemical treatments for DNA mutagenesis, transposon-based approaches provide a marked and defined mutation that can be easily identified in mutants of interest by virtue of the transposon sequence itself. CRISPR-Cas gene editing is a relevant means of generating genomic mutations. While targeted mutagenesis by CRISPR-Cas is a powerful strategy, CRISPR-based approaches do not readily allow for the scale of mutations needed to saturate a large genome. Furthermore, CRISPR-Cas strategies are not currently applicable for genome-wide screens in multicellular organisms. In contrast to targeted mutagenesis approaches, transposons can be used to generate a larger number of mutations with economy of labor and cost, although transposition bias can complicate genome-wide studies where saturating coverage is desired ${ }^{92-94}$. Insertion bias and the gene density of the targeted genome will impact the observed density of coverage by transposon mutagenesis; genomes with relatively small intergenic spaces are more easily saturated by transposon mutagenesis. Strategies employing in vitro mutagenesis with subsequent insertion alleles being introduced into the relevant organism by DNA transformation and approaches utilizing transposon mutagenesis in vivo have been used for large-scale studies. The applicability of these respective approaches depends on the density of mutations desired and the degree of insertion bias demonstrated by the transposon. In vitro transposition systems may provide less insertion bias and greater coverage, although the applicability of such systems is dependent upon the availability of efficient methods for the chromosomal integration of exogenous DNA. Notably, saturating in vivo mutagenesis has been performed in yeast $^{95}$. Many early applications of transposon mutagenesis were used for genome-wide phenotypic analysis in prokaryotes and eukaryotes $^{96-106}$, and transposon-based approaches continue to be utilized today.

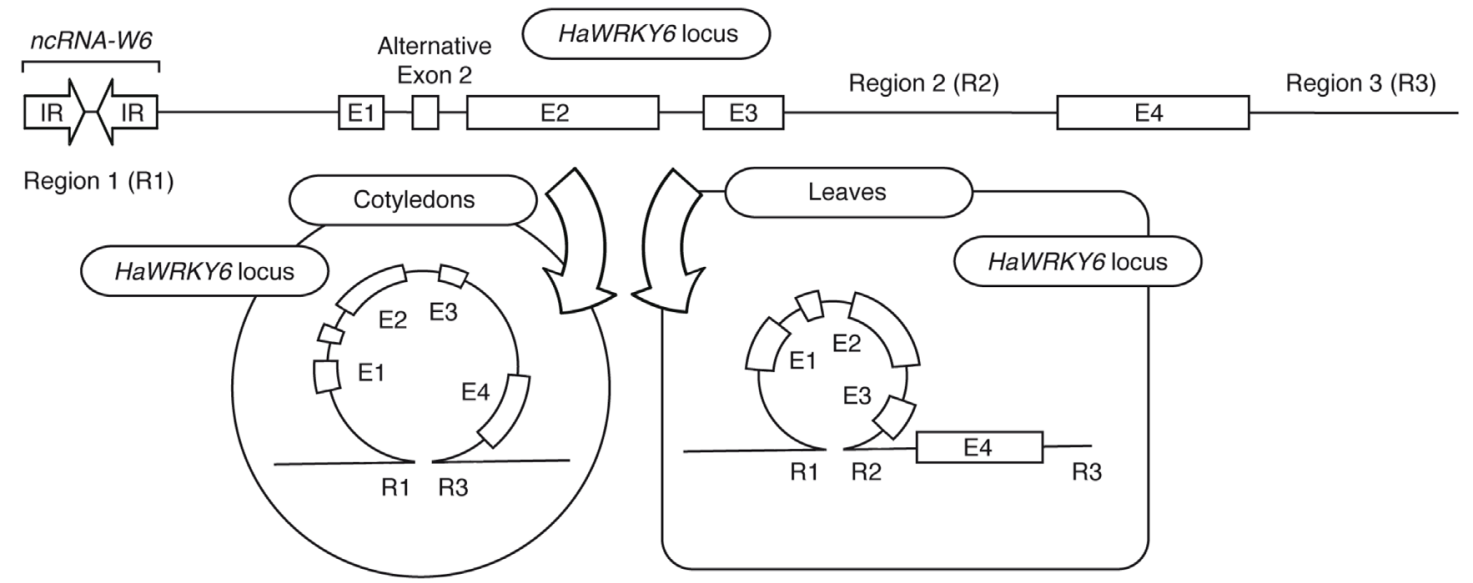

Figure 1. An inverted repeat (IR) transposable element regulates chromatin topology at the HaWRKY6 locus in sunflower. A simplified representation of the HaWRKY 6 locus is shown, with opposed arrows indicating an IR transposable element and boxed segments indicating exons (E). Regions to which small RNAs (sRNAs) were mapped are indicated (regions R1-R3). The altered chromatin structure of the locus in cotyledons and leaves is diagrammatically presented. The chromatin loop encompasses the HaWRKY 6 gene in cotyledons, enhancing transcription, while an intragenic loop forms in leaves, inhibiting transcription. The locus and exons are not drawn to scale. 
Recent screening strategies have incorporated barcodes in the transposon, enabling the construction of barcoded mutant libraries that can be effectively multiplexed or analyzed in parallel for large-scale phenotypic analysis ${ }^{107}$. Helmann et al. ${ }^{108}$ utilized random bar-coded transposon mutagenesis to identify genes contributing to the fitness of the bacterial plant pathogen Pseudomonas syringae. In this work, a collection of 281,417 mutant $P$. syringae strains in the $\mathrm{B} 278 \mathrm{a}$ background were generated by random mutagenesis using a DNA-barcoded variant of a Mariner transposon. The library encompassed 169,826 strains containing an insertion within a known gene, representing $84 \%$ of the protein-coding genes in $P$. syringae. By virtue of the incorporated barcodes, amplicon sequencing of the barcoded regions was used as a relative measure of abundance of each mutant strain and a proxy of strain fitness in pooled populations. The analysis identified at least 392 genes predicted to be essential for the growth of strain B278a under standard laboratory conditions. The work further identified a set of $P$. syringae genes required for its colonization of the surface and interior habitats of the bean Phaseolus vulgaris, collectively highlighting the utility of barcoded transposon sequencing for genome-wide mutagenesis screens.

Chang and colleagues ${ }^{109}$ have adapted transposon mutagenesis for genome-wide phenotypic screening in mice through an approach enabling the easy identification of mice with insertions, while requiring relatively modest numbers of mice and researchers. This work utilized a modified form of the DNA transposon piggyBac for use in mammalian cells and mammals. Classic systems contain a non-autonomous piggyBac transposon cassette, for the delivery of exogenous genes of interest flanked by the piggyBac IR sequences, and a transgene expressing the piggyBac transposase, enabling induced transposition in the germline ${ }^{110}$. Binding of the transposase to the IR sequences results in the excision and reintegration of the cassette at another locus. The study by Chang et al. ${ }^{109}$ presents a piggyBac construct with a conditionally regulated promoter for gene overexpression and a stop cassette with splice acceptor and poly(A) signal for efficient disruption of target transcription. Furthermore, the transposons are visually trackable, utilizing a red fluorescent protein transgene and a codon-optimized luciferase gene. Luciferase gene activity is disrupted by insertion of the piggyBac construct, and luciferase activity is restored upon excision of the insertion, providing a convenient means of visually tracking transposon mobilization. For genome-wide mutagenesis of the mouse germline, a transgenic line was generated carrying 10 copies of the piggyBac transposon. By this clever approach, Chang and colleagues implemented a cost-effective and efficient pilot first-generation F1 dominant screen for growth retardation phenotypes in mice.

The Sleeping Beauty transposon system has been used for mutagenesis in somatic tissue and holds strong potential utility for the analysis of cancer and other phenotypes both in vitro and in vivo ${ }^{11,112}$. The Sleeping Beauty system consists of the eponymous transposase and transposon, initially found in the genome of salmonid fish in the late $1990 \mathrm{~s}^{113}$. Sleeping Beauty transposons have been used extensively for insertional mutagenesis in embryonic stem cells ${ }^{114}$, somatic tissues ${ }^{15,116}$, and germline tissues ${ }^{117-119}$. Sleeping Beauty transposons have been used to identify colorectal cancer-related genes in a mouse model $^{120}$. Recently, Grisard and colleagues ${ }^{121}$ utilized a Sleeping Beauty-based forward genetic screen, coupled with single cell assays, to uncover regulators of metastatic colorectal cancer. The analyses identified the microRNA MIR23-b and BTBD7 as prognostic predictors of colorectal cancer metastasis, illustrating the utility in transposon mutagenesis relative to chemical, radiation, or viral mutagenesis for analyses of putative biomarker functions prior to clinical applications of liquid biopsy assays ${ }^{122}$.

\section{Transposons as vectors for gene therapy}

DNA transposons have emerged as viable vectors for gene therapy (reviewed in 123), such that numerous proof-of-concept studies of transposons for ex vivo and in vivo therapy in disease models now exist. Approaches including codon optimization of the transposase, the engineering of hyperactive transposases, and modification of transposon terminal repeats have improved transposition efficacy, enabling stable gene transfer in stem/progenitor cells and in differentiated cell types. With respect to Sleeping Beauty, hyperactive variants of its transposase have been generated through methods for in vitro evolution and selection ${ }^{124}$ and structure-based design/molecular engineering ${ }^{125}$. Sleeping Beauty systems have been used for the delivery of transgenes up to $8 \mathrm{~kb}$ in length ${ }^{126}$, and Sleeping Beauty has been used in phase I trials to generate CD19-specific Chimeric Antigen Receptor (CAR)-T cells for immunotherapy relevant to the treatment of non-Hodgkin lymphoma and acute lymphoblastic leukemia ${ }^{127}$. Rational protein design has been used to generate a Sleeping Beauty transposase with high solubility and stability that can be effectively delivered with transposon DNA to genetically modify cell lines, embryonic stem cells, hematopoietic stem cells, and induced pluripotent stem cells. This approach has been used to generate CAR-T cells, exhibiting potent antitumor activity in vitro and in xenograft mice ${ }^{128}$. The transposase for piggyBac has been modified by approaches utilizing codon optimization ${ }^{129}$ and the incorporation of site-specific mutations ${ }^{130}$. The piggyBac system is capable of delivering DNA cargo up to $100 \mathrm{~kb}$ in length ${ }^{131}$, including full-length human dystrophin for the treatment of dystrophic mesoangioblasts ${ }^{132}$. The Tol2 transposon system can deliver transgenes up to $11 \mathrm{~kb}$ in length and has been used in a number of transgenesis studies in zebrafish and other organisms ${ }^{133-135}$, although the efficiency of Tol2-based gene transfer may not be as high as that observed in Sleeping Beauty or piggyBac systems ${ }^{136}$.

\section{RNA-guided transposon insertion}

RNA-directed transposition provides a promising experimental approach for the generation of targeted insertions, and the CRISPR-Cas system is proving to be important for this work. Bioinformatic analyses have identified CRISPR-Cas systems encoded on some transposons, with the CRISPR-derived sequences potentially fulfilling a role unrelated to host organism defense $\mathrm{e}^{137,138}$. Variants of the E. coli transposon Tn7 (Figure 2A) have been found to encode CRISPR-Cas 
systems. Classically, Tn7 encodes TnsE, which contributes to random $\mathrm{Tn} 7$ transposition in conjugal plasmids and replicating DNA, as opposed to targeted insertion mediated through TnsD at attTn7 Tn7 attachment sites ${ }^{139}$. Tn7 variants encoding CRISPR-Cas systems lack sequence-encoding orthologs of TsnE, and the CRISPR-Cas systems lack the Cas proteins needed to acquire novel spacers and the nucleolytic activity to cleave targets ${ }^{137}$. Genes enabling target recognition are still present, suggesting that the transposons might utilize CRISPR effectors, thereby guiding transposition to targets defined by the spacers in the CRISPR arrays.

Two groups have recently demonstrated RNA-directed insertion by Tn7 relatives containing CRISPR-Cas. Strecker and colleagues $^{140}$ analyzed a Tn7-related CRISPR-associated transposase from the cyanobacterium Scytonema hofmanni, called CAST (Figure 2B). The transposase consists of Tn7-like transposase subunits TnsB, TnsC, and TniQ and the type V-K CRISPR effector Cas12k. This Tn7-like transposition can be directed to target sites by CRISPR-Cas-mediated RNA-guided targeting. Tn7 transposition can be reprogrammed to insert DNA into targeted sites in the $E$. coli genome with frequencies of up to $80 \%$ without positive selection. Klompe et al. ${ }^{141}$ identified a Vibrio cholerae CRISPR-Cas effector complex in the element Tn6677 (Figure 2C) that can direct an accompanying Tn7derived transposase to integrate DNA 48-50 bp downstream of a genomic target site complementary to a guide RNA. The Tn6677 element encodes TnsA, TnsB, TnsC, and TniQ. This transposition involves the formation of a complex between the DNA-targeting complex Cascade and the cas-encoded transposition protein TniQ, an ortholog of E. coli TnsD. The presence of TnsA allows for cut-and-paste transposition that would result in a simple insertion event. As indicated above, the CAST element lacks TnsA, and thus cleavages at the transposon 5'-ends leading to simple insertions are presumably provided by a host factor and not a component of the transposase. Maximum transposition of the Tn6677 element occurred with a $775 \mathrm{bp}$ transposon donor, requiring $105 \mathrm{bp}$ of sequence at the Tn6677-left terminus and $47 \mathrm{bp}$ of the right-end terminus. Programmable transposition of the $V$. cholerae Tn6677 element
(Figure 2C) was observed across dozens of unique target sites, indicating the potential utility in these techniques as a means of achieving site-specific DNA insertions in bacteria without the generation of a dangerous double-strand break. Notably, CRISPR-Cas mutagenesis results in a double-strand break for repair by either non-homologous end joining or homologous recombination. RNA-guided transposition holds the potential to enable targeted genomic insertion of transposable elements with potentially large cargoes at selected sites constituting "safe havens", thereby diminishing the risk of unanticipated insertional mutagenesis.

Aside from the relevance of RNA-guided transposition as a tool for biotechnology, the identification of transposon-encoded CRISPR-Cas variants poses interesting and unanswered evolutionary questions as to the apparent selective advantage in this biological design. CRISPR-Cas-guided transposition is thought to have evolved independently at least three times in Tn7-like elements ${ }^{137,138}$. As discussed by Dimitriu et al. ${ }^{142}$, this mechanism is far from ubiquitous, suggesting that balanced costs and benefits are at play in the evolution of systems for RNA-guided transposition. The ability of transposons to hijack CRISPR-Cas effector machinery may be advantageous as a means of biasing transposition towards mobile genetic elements for enhanced horizontal transfer; however, it is unclear how these CRISPR-Cas systems lacking genes needed for spacer acquisition would be able to identify rapidly evolving mobile genetic elements. Strecker et al. ${ }^{140}$ suggest that host CRISPR-Cas machinery may capture spacers for insertion into Tn7-encoded CRISPR arrays. Klompe and colleagues ${ }^{141}$ found that the vast majority of type I-F CRISPR-Cas systems within the Vibrionaceae family are associated with mobile genetic elements, consistent with the possibility that RNA-guided DNA integration may facilitate the sharing of innate immune systems and virulence mechanisms through horizontal gene transfer. Regardless of the evolutionary pressures that have driven this unexpected interrelationship, RNA-guided transposase systems are primed to be an important and rapidly expanding area of study in biotechnology and evolutionary biology fields.

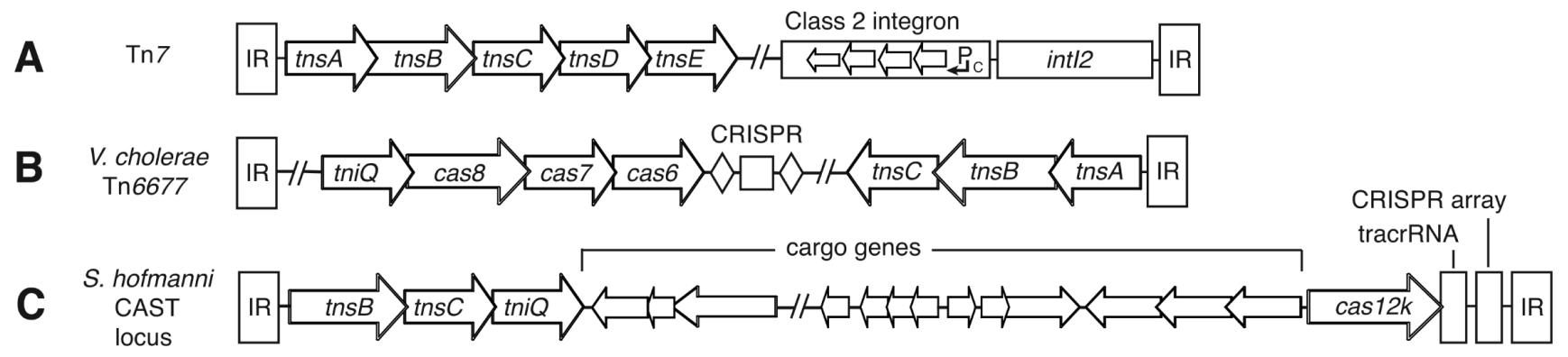

Figure 2. Sequence structure of the $\mathrm{Tn} 7$ transposon and derivatives encompassing clustered regularly interspaced palindromic repeats (CRISPR)-Cas-type systems. A) The structure of a typical Tn 7 transposon is shown, with terminal inverted repeats (IR) shown as boxes and constituent genes shown as arrows. The diagram is based on the structure of the Escherichia coli R721 shufflon. B) The structure of the Vibrio cholerae Tn6677 transposon is shown. Tn7-derived elements and the CRISPR array are indicated. C) A representation of the Scytonema hofmanni CAST locus is provided, encompassing Tn7-like open reading frames, the effector Cas12k, and the CRISPR array. The loci are not drawn to scale. 
Along these lines of generating higher efficiency systems for directed DNA delivery, Bhatt and Chalmers ${ }^{143}$ have recently co-opted Cas 9 to target integration in vitro through the reconstituted Mariner-family transposon HsMarl. For this work, a chimeric protein was generated consisting of the HsMarl transposase fused to the amino terminus of E. coli dCas9. The transposase and Cas9 moieties in the chimera were able to bind their respective substrates. Furthermore, the fusion protein was effective in targeting HsMarl activity in vitro, resulting in unidirectional integrations with a targeting efficiency of more than $50 \%$. It remains to be determined if this approach will be effective and sufficiently selective in vivo in large genomes. Hew et al. ${ }^{144}$ fused a hyperactive form of the piggyBac transposase to catalytically dead high-fidelity SpCas9HF1 (dCas9). The researchers introduced mutations to the native DNA-binding domain of piggyBac, decreasing nonspecific transposase binding and favoring binding of the chimera by dCas9. By this approach, transposition was directed to the safe harbor CCR5 sequence using appropriately designed guide RNAs. The insertion profile of Sleeping Beauty has been biased through fusion of its transposase, or an $\mathrm{N}$-terminal fragment of its transposase, with DNA-binding and protein dimerization domains ${ }^{145,146}$. Ongoing work in the Ivics laboratory is addressing the modification of Sleeping Beauty target site selection using dCas9 and a single guide RNA against the $A l u$ retrotransposon for integration in genomic regions that are otherwise poor targets for Sleeping Beauty transposition ${ }^{147}$. Cumulatively, the findings speak to the potential utility in harnessing CRISPR-Cas technology for RNA-targeted transposable element integration.

\section{Transposon-related studies in biological disciplines}

The studies above highlight the current breadth of research interests touching on the biology of transposable elements. Mechanisms of transposition and the interplay between transposons and host systems have been foci for intensive research efforts over some time, and the persistent and important questions that remain regarding these topics of study continue to prime investigations of the molecular basis of transposition and its utilization or avoidance of host biological processes. The impact of transposition on gene expression and function at insertion loci is substantial, and the disease implications of transposons as hotspots for mutation are still being understood. Transposons have also been utilized as significant tools for large-scale phenotypic screening, and recent discoveries of CRISPR-Casguided transposition hold high potential in facilitating targeted DNA integration without the off-target mutagenic potential of approaches utilizing homologous recombination. Collectively, the coming years are likely to witness expanding interest in transposon biology towards scientific advancements and the establishment of broad human health benefits.

\section{Acknowledgments}

The author wishes to thank Bagyashree Sundaram for helpful comments regarding the manuscript.
1. Hancks DC, Kazazian HH Jr: Roles for retrotransposon insertions in human disease. Mob DNA. 2016; 7: 9.

PubMed Abstract | Publisher Full Text | Free Full Text

2. Kazazian HH Jr, Moran JV: Mobile DNA in Health and Disease. N Engl J Med 2017; 377(4): 361-70.

PubMed Abstract | Publisher Full Text | Free Full Text

3. Bourque G, Burns $\mathrm{KH}$, Gehring M, et al:: Ten things you should know about transposable elements. Genome Biol. 2018; 19(1): 199. PubMed Abstract | Publisher Full Text | Free Full Text

4. Wicker $\mathrm{T}$, Gundlach $\mathrm{H}$, Spannagl $\mathrm{M}$, et al:: Impact of transposable elements on genome structure and evolution in bread wheat. Genome Biol. 2018; 19(1): 103. PubMed Abstract | Publisher Full Text | Free Full Text

5. Payer LM, Burns $\mathrm{KH}$ : Transposable elements in human genetic disease. Nat Rev Genet. 2019; 20(12): 760-72. PubMed Abstract | Publisher Full Text

6. $\quad F$ Partridge SR, Kwong SM, Firth N, et al.: Mobile Genetic Elements Associated with Antimicrobial Resistance. Clin Microbiol Rev. 2018; 31(4): pii: e00088-17. PubMed Abstract | Publisher Full Text | Free Full Text | F1000 Recommendation

7. $\mathrm{F}$ Zhao B, Wu Q, Ye AY, et al:: Somatic LINE-1 retrotransposition in cortical neurons and non-brain tissues of Rett patients and healthy individuals. PLOS Genet. 2019; 15(4): e1008043.

PubMed Abstract | Publisher Full Text | Free Full Text | F1000 Recommendation

8. Helman E, Lawrence MS, Stewart C, et al:: Somatic retrotransposition in human cancer revealed by whole-genome and exome sequencing. Genome Res. 2014; 24(7): 1053-63.

PubMed Abstract | Publisher Full Text | Free Full Text

9. $F$ Lee $E$, Iskow $R$, Yang $L$, et al.: Landscape of somatic retrotransposition in human cancers. Science. 2012; 337(6097): 967-71.

PubMed Abstract | Publisher Full Text | Free Full Text | F1000 Recommendation
10. McDonald JF: Evolution and consequences of transposable elements. Curr Opin Genet Dev. 1993; 3(6): 855-64. PubMed Abstract | Publisher Full Text

11. $\mathrm{F}$ Gagnier L, Belancio VP, Mager DL: Mouse germ line mutations due to retrotransposon insertions. Mob DNA. 2019; 10: 15. PubMed Abstract | Publisher Full Text | Free Full Text | F1000 Recommendation

12. Gross L: Transposon silencing keeps jumping genes in their place. PLOS Biol. 2006; 4(10): e353.

PubMed Abstract | Publisher Full Text | Free Full Text

13. Johnson L: Transposon silencing: the extraordinary epigenetics of a transposon trap. Heredity (Edinb). 2008; 100(1): 5. PubMed Abstract | Publisher Full Text

14. Khurana JS, Theurkauf W: piRNAs, transposon silencing, and Drosophila germline development. J Cell Biol. 2010; 191(5): 905-13. PubMed Abstract | Publisher Full Text | Free Full Text

15. Borges F, Martienssen RA: The expanding world of small RNAs in plants. Nat Rev Mol Cell Biol. 2015; 16(12): 727-41. PubMed Abstract | Publisher Full Text | Free Full Text

16. Walter M, Teissandier A, Pérez-Palacios R, et al.: An epigenetic switch ensures transposon repression upon dynamic loss of DNA methylation in embryonic transposon repression upon dynamic
stem cells. eLife. 2016; 5: pii: e11418. stem cells. eLife. 2016; 5: pil: e11418.
PubMed Abstract | Publisher Full Text | Free Full Text

17. Lander ES, Linton LM, Birren B, et al: Initial sequencing and analysis of the human genome. Nature. 2001; 409(6822): 860-921. PubMed Abstract | Publisher Full Text

18. Feschotte $C$, Pritham EJ: DNA transposons and the evolution of eukaryotic genomes. Annu Rev Genet. 2007; 41: 331-68. PubMed Abstract | Publisher Full Text | Free Full Text

19. Grandi N, Tramontano E: Human Endogenous Retroviruses Are Ancient 
Acquired Elements Still Shaping Innate Immune Responses. Front Immunol. 2018; 9: 2039

PubMed Abstract | Publisher Full Text | Free Full Text

20. F Chuong EB, Elde NC, Feschotte C: Regulatory evolution of innate immunity through co-option of endogenous retroviruses. Science. 2016; 351(6277): 1083-7.

PubMed Abstract | Publisher Full Text | Free Full Text | F1000 Recommendation

21. Göke J, Ng HH: CTRL+INSERT: retrotransposons and their contribution to regulation and innovation of the transcriptome. EMBO Rep. 2016; 17(8): $1131-44$

PubMed Abstract | Publisher Full Text | Free Full Text

22. F Pace JK 2nd, Feschotte C: The evolutionary history of human DNA transposons: evidence for intense activity in the primate lineage. Genome Res. 2007; 17(4): 422-32.

PubMed Abstract | Publisher Full Text | Free Full Text | F1000 Recommendation

23. Peccoud J, Loiseau V, Cordaux R, et al.: Massive horizontal transfer of transposable elements in insects. Proc Natl Acad Sci U S A. 2017; 114(18): $4721-6$.

PubMed Abstract | Publisher Full Text | Free Full Text

24. Gilbert C, Feschotte C: Horizontal acquisition of transposable elements and viral sequences: patterns and consequences. Curr Opin Genet Dev. 2018; 49 $15-24$.

PubMed Abstract | Publisher Full Text | Free Full Text

25. Arkhipova IR: Neutral Theory, Transposable Elements, and Eukaryotic Genome Evolution. Mol Biol Evol. 2018; 35(6): 1332-7.

PubMed Abstract | Publisher Full Text | Free Full Text

26. Zhang J, Yu C, Krishnaswamy L, et al.: Transposable elements as catalysts for chromosome rearrangements. Methods Mol Biol. 2011; 701: 315-26. PubMed Abstract | Publisher Full Text

27. Solyom S, Kazazian HH Jr: Mobile elements in the human genome: implications for disease. Genome Med. 2012; 4(2): 12

PubMed Abstract | Publisher Full Text | Free Full Text

28. Halic M, Moazed D: Transposon silencing by piRNAs. Cell. 2009; 138(6): 1058-60.

PubMed Abstract | Publisher Full Text | Free Full Text

29. F Zhao K, Cheng S, Miao N, et al:: A Pandas complex adapted for piRNAguided transcriptional silencing and heterochromatin formation. Nat Cell Biol. 2019; 21(10): 1261-72.

PubMed Abstract | Publisher Full Text | F1000 Recommendation

30. F Ozata DM, Gainetdinov I, Zoch A, et al:: PIWI-interacting RNAs: small RNAs with big functions. Nat Rev Genet. 2019; 20(2): 89-108.

PubMed Abstract | Publisher Full Text | F1000 Recommendation

31. Molaro A, Malik HS: Hide and seek: how chromatin-based pathways silence retroelements in the mammalian germline. Curr Opin Genet Dev. 2016; 37: 51-8. PubMed Abstract | Publisher Full Text | Free Full Text

32. $\mathrm{F} \mathrm{He} \mathrm{J,} \mathrm{Fu} \mathrm{X,} \mathrm{Zhang} \mathrm{M,} \mathrm{et} \mathrm{al::} \mathrm{Transposable} \mathrm{elements} \mathrm{are} \mathrm{regulated} \mathrm{by}$ context-specific patterns of chromatin marks in mouse embryonic stem cells. Nat Commun. 2019; 10(1): 34

PubMed Abstract | Publisher Full Text | Free Full Text | F1000 Recommendation

33. Ecco G, Cassano M, Kauzlaric A, et al.: Transposable Elements and Their KRABZFP Controllers Regulate Gene Expression in Adult Tissues. Dev Cell. 2016; 36(6): 611-23.

PubMed Abstract | Publisher Full Text | Free Full Text

34. Schmitges FW, Radovani E, Najafabadi HS, et al.: Multiparameter functional diversity of human C2H2 zinc finger proteins. Genome Res. 2016; 26(12): 1742-52.

PubMed Abstract | Publisher Full Text | Free Full Text

35. F Imbeault M, Helleboid PY, Trono D: KRAB zinc-finger proteins contribute to the evolution of gene regulatory networks. Nature. $2017 ; \mathbf{5 4 3}(7646)$ : 550-4 PubMed Abstract | Publisher Full Text | F1000 Recommendation

36. Yang P, Wang Y, Macfarlan TS: The Role of KRAB-ZFPs in Transposable Element Repression and Mammalian Evolution. Trends Genet. 2017; 33(11): 871-81.

PubMed Abstract | Publisher Full Text | Free Full Text

37. F Deniz Ö, Frost JM, Branco MR: Regulation of transposable elements by DNA modifications. Nat Rev Genet. 2019; 20(7): 417-31. PubMed Abstract | Publisher Full Text | F1000 Recommendation

38. F Zemach A, Kim MY, Hsieh PH, et al.: The Arabidopsis Nucleosome Remodeler DDM1 Allows DNA Methyltransferases to Access H1-Containing Heterochromatin. Cell. 2013; 153(1): 193-205.

PubMed Abstract | Publisher Full Text | Free Full Text | F1000 Recommendation

39. Dunican DS, Cruickshanks HA, Suzuki M, et al.: Lsh regulates LTR retrotransposon repression independently of Dnmt3b function. Genome Biol. 2013; 14(12): R146.

PubMed Abstract | Publisher Full Text | Free Full Text

40. Walsh CP, Chaillet JR, Bestor TH: Transcription of IAP endogenous retroviruses is constrained by cytosine methylation. Nat Genet. 1998; 20(2): 116-7. PubMed Abstract | Publisher Full Text

41. Lippman Z, May B, Yordan C, et al.: Distinct Mechanisms Determine Transposon Inheritance and Methylation via Small Interfering RNA and Histone Modification. PLOS Biol. 2003; 1(3): E67.

PubMed Abstract | Publisher Full Text | Free Full Text
42. F Bourc'his D, Bestor TH: Meiotic catastrophe and retrotransposon reactivation in male germ cells lacking Dnmt3L. Nature. 2004; 431(7004): 96-9. PubMed Abstract | Publisher Full Text | F1000 Recommendation

43. Zamudio N, Barau J, Teissandier A, et al:: DNA methylation restrains transposons from adopting a chromatin signature permissive for meiotic recombination. Genes Dev. 2015; 29(12): 1256-70.

PubMed Abstract | Publisher Full Text | Free Full Text

44. Jain D, Meydan C, Lange J, et al.: rahu is a mutant allele of Dnmt3c, encoding a DNA methyltransferase homolog required for meiosis and transposon repression in the mouse male germline. PLoS Genet. 2017; 13(8): e1006964. PubMed Abstract | Publisher Full Text | Free Full Text

45. F Chernyavskaya $\mathrm{Y}$, Mudbhary R, Zhang $\mathrm{C}$, et al:: Loss of DNA methylation in zebrafish embryos activates retrotransposons to trigger antiviral signaling. Development. 2017; 144(16): 2925-39.

PubMed Abstract | Publisher Full Text | Free Full Text | F1000 Recommendation

46. Zhou Y, Cambareri EB, Kinsey JA: DNA methylation inhibits expression and transposition of the Neurospora Tad retrotransposon. Mol Genet Genomics. 2001; 265(4): 748-54.

PubMed Abstract | Publisher Full Text

47. Zhang G, Huang $\mathrm{H}$, Liu D, et al:: N6-methyladenine DNA modification in Drosophila. Cell. 2015; 161(4): 893-906. PubMed Abstract | Publisher Full Text

48. Roberts $\mathrm{D}$, Hoopes $\mathrm{BC}, \mathrm{McClure}$ WR, et al:: IS10 transposition is regulated by DNA adenine methylation. Cell. 1985; 43(1): 117-30. PubMed Abstract | Publisher Full Text

49. Fu Y, Luo G-Z, Chen $\mathrm{K}$, et al:: $\boldsymbol{N}^{6}$-methyldeoxyadenosine marks active transcription start sites in Chlamydomonas. Cell. 2015; 161(4): 879-92. PubMed Abstract | Publisher Full Text | Free Full Text

50. Greer EL, Blanco MA, Gu L, et al.: DNA Methylation on N6-Adenine in C. elegans. Cell. 2015; 161(4): 868-78. PubMed Abstract | Publisher Full Text | Free Full Text

51. O'Brown ZK, Greer EL: N6-Methyladenine: A Conserved and Dynamic DNA Mark. Adv Exp Med Biol. 2016; 945: 213-46. PubMed Abstract | Publisher Full Text | Free Full Text

52. F Xiao CL, Zhu S, He M, et al.: N6-Methyladenine DNA Modification in the Human Genome. Mol Cell. 2018; 71(2): 306-318.e7. PubMed Abstract | Publisher Full Text | F1000 Recommendation

53. Liu J, Zhu Y, Luo GZ, et al.: Abundant DNA 6mA methylation during early embryogenesis of zebrafish and pig. Nat Commun. 2016; 7: 13052. PubMed Abstract | Publisher Full Text | Free Full Text

54. F Cosby RL, Chang NC, Feschotte C: Host-transposon interactions: Conflict, cooperation, and cooption. Genes Dev. 2019; 33(17-18): 1098-116. PubMed Abstract | Publisher Full Text | Free Full Text | F1000 Recommendation

55. von Wintersdorff CJ, Penders J, van Niekerk JM, et al.: Dissemination of Antimicrobial Resistance in Microbial Ecosystems through Horizontal Gene Transfer. Front Microbiol. 2016; 7: 173.

PubMed Abstract | Publisher Full Text | Free Full Text

56. F Durrant MG, Li MM, Siranosian BA, et al:: A Bioinformatic Analysis of ntegrative Mobile Genetic Elements Highlights Their Role in Bacterial Adaptation. Cell Host Microbe. 2020; 27(1): 140-153.e9. PubMed Abstract | Publisher Full Text | Free Full Text | F1000 Recommendation

57. Phale PS, Shah BA, Malhotra H: Variability in Assembly of Degradation Operons for Naphthalene and its derivative, Carbaryl, Suggests Mobilization through Horizontal Gene Transfer. Genes (Basel). 2019; 10(8): pii: E569. PubMed Abstract | Publisher Full Text | Free Full Text

58. F Haurwitz RE, Jinek M, Wiedenheft B, et al: Sequence- and structure-specific RNA processing by a CRISPR endonuclease. Science. 2010; 329(5997): 1355-8. PubMed Abstract | Publisher Full Text | Free Full Text | F1000 Recommendation

59. F Wiedenheft B, Lander GC, Zhou K, et al:: Structures of the RNA-guided surveillance complex from a bacterial immune system. Nature. 2011; $477(7365)$ 486-9.

PubMed Abstract | Publisher Full Text | Free Full Text | F1000 Recommendation

60. F Jinek M, Chylinski K, Fonfara I, et al.: A programmable dual-RNA-guided DNA endonuclease in adaptive bacterial immunity. Science. 2012; 337(6096): $816-21$.

PubMed Abstract | Publisher Full Text | Free Full Text | F1000 Recommendation

61. F Cong L, Ran FA, Cox D, et al:: Multiplex Genome Engineering Using CRISPR/Cas Systems. Science. 2013; 339(6121): 819-23. PubMed Abstract | Publisher Full Text | Free Full Text | F1000 Recommendation

62. Koonin EV, Krupovic M: Evolution of adaptive immunity from transposable elements combined with innate immune systems. Nat Rev Genet. 2015; 16(3): 184-92.

PubMed Abstract | Publisher Full Text | Free Full Text

63. Krupovic M, Béguin P, Koonin EV: Casposons: Mobile genetic elements that gave rise to the CRISPR-Cas adaptation machinery. Curr Opin Microbiol. 2017; 38: $36-43$.

PubMed Abstract | Publisher Full Text | Free Full Text

64. Carmona LM, Schatz DG: New insights into the evolutionary origins of the recombination-activating gene proteins and $V(D) J$ recombination. FEBS $J$. 2017; 284(11): 1590-605.

PubMed Abstract | Publisher Full Text | Free Full Text 
65. F Huang S, Tao X, Yuan S, et al.: Discovery of an Active RAG Transposon Illuminates the Origins of V(D)J Recombination. Cell. 2016; 166(1): 102-14. PubMed Abstract | Publisher Full Text | Free Full Text | F1000 Recommendation

66. F Liu C, Yang Y, Schatz DG: Structures of a RAG-like transposase during cutand-paste transposition. Nature. 2019; 575(7783): 540-4.

PubMed Abstract | Publisher Full Text | Free Full Text | F1000 Recommendation

67. Casacuberta E: Drosophila: Retrotransposons Making up Telomeres. Viruses. 2017; 9(7): pii: E192.

PubMed Abstract | Publisher Full Text | Free Full Text

68. Pardue ML, Debaryshe P: Adapting to life at the end of the line: How Drosophila telomeric retrotransposons cope with their job. Mob Genet Elements. 2011: 1(2): 128-34.

PubMed Abstract | Publisher Full Text | Free Full Text

69. Pardue ML, DeBaryshe PG: Retrotransposons that maintain chromosome ends. Proc Natl Acad Sci U S A. 2011; 108(51): 20317-24. PubMed Abstract | Publisher Full Text | Free Full Text

70. $\mathrm{F}$ Chang $\mathrm{CH}$, Chavan $\mathrm{A}$, Palladino $\mathrm{J}$, et al:: Islands of retroelements are major components of Drosophila centromeres. PLOS Biol. 2019; 17(5): e3000241. PubMed Abstract | Publisher Full Text | Free Full Text | F1000 Recommendation

71. F McDonald MC, Taranto AP, Hill E, et al:: Transposon-Mediated Horizonta Transfer of the Host-Specific Virulence Protein ToxA between Three Fungal Wheat Pathogens. mBio. 2019; 10(5): pii: e01515-19.

PubMed Abstract | Publisher Full Text | Free Full Text | F1000 Recommendation

72. Nowacki M, Higgins BP, Maquilan GM, et al.: A functional role for transposases in a large eukaryotic genome. Science. 2009; 324(5929): 935-8. PubMed Abstract | Publisher Full Text | Free Full Text

73. Vogt A, Goldman AD, Mochizuki K, et al:: Transposon Domestication versus Mutualism in Ciliate Genome Rearrangements. PLoS Genet. 2013; 9(8): e1003659.

PubMed Abstract | Publisher Full Text | Free Full Text

74. Chen X, Bracht JR, Goldman AD, et al:: The architecture of a scrambled genome reveals massive levels of genomic rearrangement during development. Cell. 2014; 158(5): 1187-98.

PubMed Abstract | Publisher Full Text | Free Full Text

75. Chen X, Landweber LF: Phylogenomic analysis reveals genome-wide purifying selection on TBE transposons in the ciliate Oxytricha. Mob DNA. 2016; 7: 2. PubMed Abstract | Publisher Full Text | Free Full Text

76. Dupressoir A, Lavialle C, Heidmann T: From ancestral infectious retroviruses to bona fide cellular genes: Role of the captured syncytins in placentation. Placenta. 2012; 33(9): 663-71.

PubMed Abstract | Publisher Full Text

77. Chuong EB: The placenta goes viral: Retroviruses control gene expression in pregnancy. PLOS Biol. 2018; 16(10): e3000028. PubMed Abstract | Publisher Full Text | Free Full Text

78. Huff JT, Zilberman D, Roy SW: Mechanism for DNA transposons to generate introns on genomic scales. Nature. 2016; 538(7626): 533-6. PubMed Abstract | Publisher Full Text | Free Full Text

79. Sundaram V, Choudhary MN, Pehrsson E, et al.: Functional cis-regulatory modules encoded by mouse-specific endogenous retrovirus. Nat Commun. 2017; 8: 14550 .

PubMed Abstract | Publisher Full Text | Free Full Text

80. Bire S, Casteret S, Piégu B, et al:: Mariner Transposons Contain a Silencer: Possible Role of the Polycomb Repressive Complex 2. PLoS Genet. 2016; 12(3): e1005902.

PubMed Abstract | Publisher Full Text | Free Full Text

81. Sundaram V, Wang $\mathrm{T}$ : Transposable Element Mediated Innovation in Gene Regulatory Landscapes of Cells: Re-Visiting the "Gene-Battery" Model. Bioessays. 2018: 40(1): 1700155.

PubMed Abstract | Publisher Full Text | Free Full Text

82. Rebollo R, Romanish MT, Mager DL: Transposable elements: an abundant and natural source of regulatory sequences for host genes. Annu Rev Genet. 2012; 46: $21-42$

PubMed Abstract | Publisher Full Text

83. $F$ Sun $X$, Wang $X$, Tang $Z$, et al: Transcription factor profiling reveals molecular choreography and key regulators of human retrotransposon expression. Proc Natl Acad Sci U S A. 2018; 115(24): E5526-E5535. PubMed Abstract | Publisher Full Text | Free Full Text | F1000 Recommendation

84. Chuong EB, Elde NC, Feschotte C: Regulatory activities of transposable elements: from conflicts to benefits. Nat Rev Genet. 2017; 18(2): 71-86. PubMed Abstract | Publisher Full Text | Free Full Text

85. F Ellison $\mathrm{C}$, Bachtrog $\mathrm{D}$ : Contingency in the convergent evolution of a regulatory network: Dosage compensation in Drosophila. PLOS Biol. 2019; 17(2): e3000094.

PubMed Abstract | Publisher Full Text | Free Full Text | F1000 Recommendation

86. F Todd CD, Deniz Ö, Taylor D, et al.: Functional evaluation of transposable elements as enhancers in mouse embryonic and trophoblast stem cells. eLife. 2019; 8: pii: e44344.

PubMed Abstract | Publisher Full Text | Free Full Text | F1000 Recommendation

87. Fuentes DR, Swigut T, Wysocka J: Systematic perturbation of retroviral LTRs reveals widespread long-range effects on human gene regulation. Elife. 2018; 7: pii: e35989.

PubMed Abstract | Publisher Full Text | Free Full Text
88. F Pontis J, Planet E, Offner S, et al:: Hominoid-Specific Transposable Elements and KZFPs Facilitate Human Embryonic Genome Activation and Control Transcription in Naive Human ESCs. Cell Stem Cell. 2019; 24(5): 724-735.e5.

PubMed Abstract | Publisher Full Text | Free Full Text | F1000 Recommendation

89. F Tellier M, Chalmers R: Human SETMAR is a DNA sequence-specific histone-methylase with a broad effect on the transcriptome. Nucleic Acids Res. 2019; 47(1): 122-33.

PubMed Abstract | Publisher Full Text | Free Full Text | F1000 Recommendation

90. F Gagliardi D, Cambiagno DA, Arce AL, et al.: Dynamic regulation of chromatin topology and transcription by inverted repeat-derived small RNAs in sunflower. Proc Natl Acad Sci U S A. 2019; 116(35): 17578-83.

PubMled Abstract | Publisher Full Text | Free Full Text | F1000 Recommendation

91. Wessler S, Bureau TE, White SE: LTR-retrotransposons and MITEs: important players in the evolution of plant genomes. Curr Opin Genet Dev. 1995; 5(6): $814-21$.

PubMed Abstract | Publisher Full Text

92. Liao GC, Rehm EJ, Rubin GM: Insertion site preferences of the $\mathbf{P}$ transposable element in Drosophila melanogaster. Proc Natl Acad Sci U S A. 2000; 97(7): 3347-51

PubMed Abstract | Publisher Full Text | Free Full Text

93. Seringhaus M, Kumar A, Hartigan J, et al:: Genomic analysis of insertion behavior and target specificity of mini-Tn7 and Tn3 transposons in Saccharomyces cerevisiae. Nucleic Acids Res. 2006; 34(8): e57. PubMed Abstract | Publisher Full Text | Free Full Text

94. Kumar A: Using Yeast Transposon-Insertion Libraries for Phenotypic Screening and Protein Localization. Cold Spring Harb Protoc. 2016; 2016(6): pdb. prot085217.

PubMed Abstract | Publisher Full Text

95. Guo Y, Park JM, Cui B, et al.: Integration profiling of gene function with dense maps of transposon integration. Genetics. 2013; 195(2): 599-609. PubMed Abstract | Publisher Full Text | Free Full Text

96. Spradling AC, Stern DM, Kiss I, et al:: Gene disruptions using $\mathbf{P}$ transposable elements: an integral component of the Drosophila genome project. Proc Nat Acad Sci U S A. 1995; 92(24): 10824-30.

PubMed Abstract | Publisher Full Text | Free Full Text

97. Ross-Macdonald P, Coelho PS, Roemer T, et al.: Large-scale analysis of the yeast genome by transposon tagging and gene disruption. Nature. 1999; 402(6760): 413-8

PubMed Abstract | Publisher Full Text

98. Kumar A, Harrison PM, Cheung KH, et al:: An integrated approach for finding overlooked genes in yeast. Nat Biotechnol. 2002; 20(1): 58-63. PubMed Abstract | Publisher Full Text

99. F Kumar A, Agarwal S, Heyman JA, et al.: Subcellular localization of the yeast proteome. Genes Dev. 2002; 16(6): 707-19. PubMed Abstract | Publisher Full Text | Free Full Text | F1000 Recommendation

100. Castano I, Kaur R, Pan S, et al:: Tn7-based genome-wide random insertional mutagenesis of Candida glabrata. Genome Res. 2003; 13(5): 905-15. PubMed Abstract | Publisher Full Text | Free Full Text

101. F Uhl MA, Biery M, Craig N, et al.: Haploinsufficiency-based large-scale forward genetic analysis of filamentous growth in the diploid human fungal pathogen C.albicans. EMBO J. 2003; 22(11): 2668-78. PubMed Abstract | Publisher Full Text | Free Full Text | F1000 Recommendation

102. Kumar A, Seringhaus M, Biery MC, et al:: Large-scale mutagenesis of the yeast genome using a Tn7-derived multipurpose transposon. Genome Res. 2004; 14(10A): 1975-86 PubMed Abstract | Publisher Full Text | Free Full Text

103. Jin R, Dobry CJ, McCown PJ, et al.: Large-scale analysis of yeast filamentous growth by systematic gene disruption and overexpression. Mol Biol Cell. 2008; 19(1): 284-96.

PubMed Abstract | Publisher Full Text | Free Full Text

104. F Bharucha N, Chabrier-Rosello $\mathrm{Y}, \mathrm{Xu} \mathrm{T}$, et al: A large-scale complex haploinsufficiency-based genetic interaction screen in Candida albicans: analysis of the RAM network during morphogenesis. PLoS Genet. 2011; 7(4): e1002058.

PubMed Abstract | Publisher Full Text | Free Full Text | F1000 Recommendation

105. Liu H, Bouillaut $\mathrm{L}$, Sonenshein $\mathrm{AL}$, et al.: Use of a mariner-based transposon mutagenesis system to isolate Clostridium perfringens mutants deficient in gliding motility. J Bacteriol. 2013; 195(3): 629-36. PubMed Abstract | Publisher Full Text | Free Full Text

106. Horton BN, Kumar A: Genome-wide synthetic genetic screening by transposon mutagenesis in Candida albicans. Methods Mol Biol. 2015; 1279: 125-35. PubMed Abstract | Publisher Full Text | Free Full Text

107. Chao MC, Abel S, Davis BM, et al.: The design and analysis of transposon insertion sequencing experiments. Nat Rev Micro. 2016; 14(2): 119-28. PubMed Abstract | Publisher Full Text | Free Full Text

108. F Helmann TC, Deutschbauer AM, Lindow SE: Genome-wide identification of Pseudomonas syringae genes required for fitness during colonization of the leaf surface and apoplast. Proc Natl Acad Sci U S A. 2019; 116(38): 18900-10. PubMed Abstract | Publisher Full Text | Free Full Text | F1000 Recommendation

109. $\mathrm{F}$ Chang $\mathrm{H}, \mathrm{Pan} \mathrm{Y}$, Landrette $\mathrm{S}$, et al:: Efficient genome-wide first-generation phenotypic screening system in mice using the piggyBac transposon. Proc 
Natl Acad Sci U S A. 2019; 116(37): 18507-16

PubMed Abstract | Publisher Full Text | Free Full Text | F1000 Recommendation

110. F Ding S, Wu X, Li G, et al.: Efficient transposition of the piggyBac (PB) transposon in mammalian cells and mice. Cell. 2005; 122(3): 473-83. PubMed Abstract | Publisher Full Text | F1000 Recommendation

111. Weiser KC, Justice MJ: Cancer biology: Sleeping Beauty awakens. Nature. 2005; 436(7048): 184-6.

PubMed Abstract | Publisher Full Text

112. Ammar I, Izsvák Z, Ivics Z: The Sleeping Beauty transposon toolbox. Methods Mol Biol. 2012; 859: 229-40. PubMed Abstract | Publisher Full Text

113. Ivics Z, Hackett PB, Plasterk RH, et al:: Molecular reconstruction of Sleeping Beauty, a Tc1-like transposon from fish, and its transposition in human cells. Cell. 1997; 91(4): 501-10.

PubMed Abstract | Publisher Full Text

114. F Kokubu $\mathrm{C}$, Horie $\mathrm{K}$, Abe $\mathrm{K}$, et al:: A transposon-based chromosomal engineering method to survey a large cis-regulatory landscape in mice. Nat Genet 2009; 41(8): 946-52.

PubMed Abstract | Publisher Full Text | F1000 Recommendation

115. F Collier LS, Carlson CM, Ravimohan S, et al:: Cancer gene discovery in solid tumours using transposon-based somatic mutagenesis in the mouse. Nature. 2005; 436(7048): 272-6.

PubMed Abstract | Publisher Full Text | F1000 Recommendation

116. F Dupuy AJ, Akagi K, Largaespada DA, et al.: Mammalian mutagenesis using a highly mobile somatic Sleeping Beauty transposon system. Nature. 2005; 436(7048): 221-6.

PubMed Abstract | Publisher Full Text | F1000 Recommendation

117. Fischer SE, Wienholds E, Plasterk RH: Regulated transposition of a fish transposon in the mouse germ line. Proc Natl Acad Sci U S A. 2001; 98(12): 6759-64. PubMed Abstract | Publisher Full Text | Free Full Text

118. Carlson CM, Dupuy AJ, Fritz S, et al.: Transposon mutagenesis of the mouse germline. Genetics. 2003; 165(1): 243-56. PubMed Abstract | Free Full Text

119. Kitada K, Ishishita S, Tosaka K, et al.: Transposon-tagged mutagenesis in the rat. Nat Meth. 2007; 4(2): 131-3. PubMed Abstract | Publisher Full Text

120. Starr TK, Allaei R, Silverstein KAT, et al:: A transposon-based genetic screen in mice identifies genes altered in colorectal cancer. Science. 2009; 323(5922): 1747-50.

PubMed Abstract | Publisher Full Text | Free Full Text

121. F Grisard $\mathrm{E}$, Coan $\mathrm{M}$, Cesaratto $\mathrm{L}$, et al.: Sleeping beauty genetic screen identifies miR-23b::BTBD7 gene interaction as crucial for colorectal cancer metastasis. EBioMedicine. 2019; 46: 79-93.

PubMed Abstract | Publisher Full Text | Free Full Text | F1000 Recommendation

122. Heitzer E, Haque IS, Roberts CES, et al.: Current and future perspectives of liquid biopsies in genomics-driven oncology. Nat Rev Genet. 2019; 20(2): $71-88$.

PubMed Abstract | Publisher Full Text

123. Tipanee J, VandenDriessche T, Chuah MK: Transposons: Moving Forward from Preclinical Studies to Clinical Trials. Hum Gene Ther. 2017; 28(11): 1087-104. PubMed Abstract | Publisher Full Text

124. F Mátés L, Chuah MK, Belay E, et al:: Molecular evolution of a novel hyperactive Sleeping Beauty transposase enables robust stable gene transfer in vertebrates. Nat Genet. 2009; 41(6): 753-61. PubMed Abstract | Publisher Full Text | F1000 Recommendation

125. Voigt $\mathrm{F}$, Wiedemann L, Zuliani $\mathrm{C}$, et al.: Sleeping Beauty transposase structure allows rational design of hyperactive variants for genetic engineering. Nat Commun. 2016; 7: 11126

PubMed Abstract | Publisher Full Text | Free Full Text

126. Geurts AM, Yang Y, Clark KJ, et al.: Gene transfer into genomes of human cells by the sleeping beauty transposon system. Mol Ther. 2003; 8(1): 108-17. PubMed Abstract | Publisher Full Text

127. Kebriaei $P$, Singh $H$, Huls $M H$, et al:: Phase I trials using Sleeping Beauty to generate CD19-specific CAR T cells. J Clin Invest. 2016; 126(9): 3363-76. PubMed Abstract | Publisher Full Text | Free Full Text

128. F Querques I, Mades A, Zuliani C, et al.: A highly soluble Sleeping Beauty transposase improves control of gene insertion. Nat Biotechnol. 2019; 37(12) 1502-12.

PubMed Abstract | Publisher Full Text | Free Full Text | F1000 Recommendation
129. F Lacoste A, Berenshteyn F, Brivanlou AH: An efficient and reversible ransposable system for gene delivery and lineage-specific differentiation in human embryonic stem cells. Cell Stem Cell. 2009; 5(3): 332-42. PubMed Abstract | Publisher Full Text | F1000 Recommendation

130. F Yusa K, Zhou L, Li MA, et al:: A hyperactive piggyBac transposase for mammalian applications. Proc Natl Acad Sci U S A. 2011; 108(4): 1531-6. PubMed Abstract | Publisher Full Text | Free Full Text | F1000 Recommendation

131. Katter K, Geurts AM, Hoffmann O, et al:: Transposon-mediated transgenesis, transgenic rescue, and tissue-specific gene expression in rodents and rabbits. FASEB J. 2013; 27(3): 930-41.

PubMled Abstract | Publisher Full Text | Free Full Text

132. Loperfido M, Jarmin S, Dastidar S, et al.: piggyBac transposons expressing full-length human dystrophin enable genetic correction of dystrophic mesoangioblasts. Nucleic Acids Res. 2016; 44(2): 744-60. PubMed Abstract | Publisher Full Text | Free Full Text

133. Balciunas D, Wangensteen $\mathrm{KJ}$, Wilber $\mathrm{A}$, et al:: Harnessing a high cargo-capacity transposon for genetic applications in vertebrates. PLOS Genet. 2006; 2(11): e169.

PubMed Abstract | Publisher Full Text | Free Full Text

134. Ni J, Wangensteen KJ, Nelsen D, et al:: Active recombinant Tol2 transposase for gene transfer and gene discovery applications. Mob DNA. 2016; 7: 6 . PubMed Abstract | Publisher Full Text | Free Full Text

135. Meir YJJ, Weirauch MT, Yang HS, et al:: Genome-wide target profiling of piggyBac and Tol2in HEK 293: Pros and cons for gene discovery and gene therapy. BMC Biotechnol. 2011; 11: 344. PubMed Abstract | Publisher Full Text | Free Full Text

136. Grabundzija I, Irgang M, Mátés L, et al.: Comparative analysis of transposable element vector systems in human cells. Mol Ther. 2010; 18(6): 1200-9. PubMed Abstract | Publisher Full Text | Free Full Text

137. F Peters JE, Makarova KS, Shmakov S, et al.: Recruitment of CRISPR-Cas systems by Tn7-like transposons. Proc Natl Acad Sci U S A. 2017; 114(35): E7358-E7366.

PubMed Abstract | Publisher Full Text | Free Full Text | F1000 Recommendation

138. F Faure G, Shmakov SA, Yan WX, et al.: CRISPR-Cas in mobile genetic elements: Counter-defence and beyond. Nat Rev Microbiol. 2019; 17(8): 513-25.

PubMed Abstract | Publisher Full Text | F1000 Recommendation

139. Waddell CS, Craig NL: Tn7 transposition: Two transposition pathways directed by five Tn7-encoded genes. Genes Dev. 1988; 2(2): 137-49. PubMed Abstract | Publisher Full Text

140. F Strecker J, Ladha A, Gardner Z, et al.: RNA-guided DNA insertion with CRISPR-associated transposases. Science. 2019; 365(6448): 48-53. PubMed Abstract | Publisher Full Text | Free Full Text | F1000 Recommendation

141. F Klompe SE, Vo PLH, Halpin-Healy TS, et al.: Transposon-encoded CRISPRCas systems direct RNA-guided DNA integration. Nature. 2019; 571(7764): 219-25.

PubMed Abstract | Publisher Full Text | F1000 Recommendation

142. F Dimitriu T, Ashby B, Westra ER: Transposition: A CRISPR Way to Get Around. Curr Biol. 2019; 29(18): R886-R889. PubMed Abstract | Publisher Full Text | F1000 Recommendation

143. F Bhatt S, Chalmers R: Targeted DNA transposition in vitro using a dCas9transposase fusion protein. Nucleic Acids Res. 2019; 47(15): 8126-35. PubMed Abstract | Publisher Full Text | Free Full Text | F1000 Recommendation

144. F Hew BE, Sato R, Mauro D, et al:: RNA-guided piggyBac transposition in human cells. Synth Biol (Oxf). 2019; 4(1): ysz018. PubMed Abstract | Publisher Full Text | Free Full Text | F1000 Recommendation

145. Voigt K, Gogol-Döring A, Miskey C, et al.: Retargeting Sleeping Beauty Transposon Insertions by Engineered Zinc Finger DNA-binding Domains. Mo Ther. 2012; 20(10): 1852-62.

PubMed Abstract | Publisher Full Text | Free Full Text

146. Ammar I, Gogol-Döring A, Miskey C, et al.: Retargeting transposon insertions by the adeno-associated virus Rep protein. Nucleic Acids Res. 2012; 40(14): 6693-712.

PubMed Abstract | Publisher Full Text | Free Full Text

147. Kovac A, Miskey C, Menzel M, et al.: RNA-guided retargeting of Sleeping Beauty transposition in human cells. bioRxiv. 2019; 848309. Publisher Full Text 


\section{Open Peer Review}

\section{Current Peer Review Status:}

\section{Editorial Note on the Review Process}

Faculty Reviews are review articles written by the prestigious Members of Faculty Opinions. The articles are commissioned and peer reviewed before publication to ensure that the final, published version is comprehensive and accessible. The reviewers who approved the final version are listed with their names and affiliations.

\section{The reviewers who approved this article are:}

\section{Version 1}

\section{Zoltán Ivics}

Division of Medical Biotechnology, Paul Ehrlich Institute, Langen, Germany

Competing Interests: No competing interests were disclosed.

\section{Nancy Craig}

Department of Molecular Biology and Genetics, Johns Hopkins School of Medicine, Baltimore, MD, USA

Competing Interests: No competing interests were disclosed.

The benefits of publishing with F1000Research:

- Your article is published within days, with no editorial bias

- You can publish traditional articles, null/negative results, case reports, data notes and more

- The peer review process is transparent and collaborative

- Your article is indexed in PubMed after passing peer review

- Dedicated customer support at every stage

For pre-submission enquiries, contact research@f1000.com 